\title{
THE MINERALOGY OF GOLD-COPPER SKARN RELATED PORPHYRY AT THE BATU HIJAU DEPOSIT, SUMBAWA, INDONESIA
}

\author{
May Thwe Aye ${ }^{* 1}$, Subagyo Pramumijoyo ${ }^{1}$, Arifudin Idrus ${ }^{1}$, Lucas Donny Setijadji ${ }^{1}$, Akira \\ Imai $^{2}$, Naoto Araki ${ }^{2}$, and Johan Arif ${ }^{3}$ \\ ${ }^{1}$ Department of Geological Engineering, Gadjah Mada University, Indonesia \\ ${ }^{2}$ Department of Earth Resources Engineering, Kyushu University, Japan \\ ${ }^{3}$ Mine Geology Department, PT Newmont Nusa Tenggara, Indonesia
}

\begin{abstract}
Clacic gold-copper bearing skarn in the Batu Hijau porphyry deposit is located in the western part of Sumbawa Island, Indonesia. Skarn mineralizations were found at the deep level of the deposit $(-450 \mathrm{~m}$ to $-1050 \mathrm{~mL}$ ) by drilling program 2003. No evidence around Batu Hijau has limestone although most skarn are metasomatized from carbonate-rich rock as limestone or marble. Most skarn-type metasomatic alteration and mineralization occurs at the contact of andesitic volcanic rock and intermediate tonalite porphyry intrusion and within intermediate tonalite in some. Although both endoskarn and exoskarn can be developed, it has no clear minerals to known the endoskarn. Exoskarn is more principle skarn zone. The formation of skarn occurred two min stages: (1) prograde and (2) retrograde. The prograde stage is temporally and spatially divided into two sub-stages as early prograde (sub-stage I) and prograde metasomatic (sub-stage II). Sub-stage I begin immediately after the intrusion of the tonalite stock into the calcium rich volcanic rocks. Then, sub-stage II originated with segregation and evolution of a fluid phase in the pluton and its invasion into fractures and micro-fractures of host rocks developed during substage I. The introduction of considerable amount of $\mathrm{Fe}$, Si and $\mathrm{Mg}$ led to the large amounts of mediumto coarse-grained anhydrous calc-silicates. From the
\end{abstract}

${ }^{*}$ Corresponding author: M.T. AYE, Department of Geological Engineering, Gadjah Mada University, Indonesia. E-mail: maythweaye@gmail.com texture and mineralogy, the retrograde metasomatic stage can be divided into two sub-stages: (a) early retrograde and (sub-stage III) and (b) late retrograde (sub-stage IV). During sub-stage III, the previously formed skarn zones were affected by intense multiple hydro-fracturing phases in the gold-copper bearing stocks. Therefore, the considerable amounts of hydrous calc-silicates (epidote), sulfides (pyrite, chalcopyrite, sphalerite), oxides (magnetite, hematite) and carbonates (calcite) replaced the anhydrous calcsilicates. Sub-stage IV was coexisting with the intrusion of relatively low temperature, more highly oxidizing fluids into skarn system, bringing about partial alteration of the early-formed calc-silicates and developing a series of very fine-grained aggregrates of chlorite, clay, hematite and calcite.

Key words: Gold-copper skarn, metasomatic alteration, Batu Hijau, Indonesia

\section{Introduction}

Gold-copper skarns probably the world's most abundant among skarn types, which can be mainly produced in orogenic zones related to subduction zone setting, both in oceanic and continental settings (Einaudi, 1982a and Einaudi, 1982b; Einaudi et al., 1981). Most are associated with I-type calc-alkalic, porphyritic plutons and form along the contact with intrusive stocks (Meinert, 1992).

The Batu Hijau deposit, the gold-copper skarn related porphyry deposit is located in the 
southwestern part of Sumbawa Island, Indonesia (Figure 1a). The skarn was formed in deep level of the deposit from $-450 \mathrm{~m}$ to $-1050 \mathrm{~mL}$. andesisitc volcaniclastic rock. Ore grade in skarn mineralizaion $(1.7 \mathrm{~g} / \mathrm{tAu}$ and $>4 \% \mathrm{Cu})$ which mainly occurred in the magnetite broken zone. Proffett (2003) firstly introduced and Steyankha et al. (2008) reported about skarn mineralization by microscopic examination and Idrus et al. (2009b) carried out some preliminary investigations on the alteration and mineralization in this skarn. In this study, focuses principally on more detailed geologic aspects, such as skarn mineralogy, texture and zonation, considers metamorphic and metasomatic alteration and mineralization during prograde and retrograde stages of skarn forming processes and finally deals with mineralizing fluids which controlled the skarn mineral assemblages.

\section{Background geology of skarn}

The skarn mineralization at the Batu Hijau deposit is closely related to the intermediate tonalite hosting a porphyry copper-type deposit. The Early to Middle Pliocene porphyry mineralization associated with tonalite porphyry stock intruded the Early to Middle Miocene andesitic volcanic rocks which host the skarn rocks. Figure $1 \mathrm{~b}$ shows the geological map of Batu Hijau illustrating the bore hole location of skarn distribution. The skarn ores are used to be exploited in the skarn zone and the contact of cacic rich volcanic rock and the adjacent of intermediate tonalite porphyry stock in Figure $1 c$. The size of skarn can only estimate approximately $400 \mathrm{~m}$ thick by drill hole data caused by most skarn occurrences from -500 to $-900 \mathrm{~mL}$ by drill hole. The associated contact metasomatic alteration and skarn mineralization are well developed in places where the fracture density in the host rocks is relatively high. Metasomatic effects are well prominent at the contact of intermediate tonalite porphyry stock with andesitic volcanic rocks, and reduce gradually outwards from the contact.

\section{Method of investigation}

Some representative samples from the skarn rocks were thin-sectioned and examined microscopically. The XRD technique was employed when microscopic identification for minerals was uncertain. Scanning Electron Microscope (SEM/EDX) was used for determining the composition of anhydrous silicates, such as pyroxenes and garnets, accurately. These analyses were carried out at the Department of Earth Resources Engineering, Faculty of engineering, Kyushu University, Japan.

\section{Petrography}

\subsection{Andesisitc volcaniclastic rocks}

The andesisitc volcaniclastic rocks consist of two majoir units: a lower sequence of finegrained volcaniclastic and an upper sequence of volcanic lithic breccia (McPhie et al., 1993). The later is the most wide spread unit of the study area and also the protolith for the skarn (Figure 1b). Megascopically, they are greenish gray to dark gray, massive to stratified, crystal and lithic-rich volcanic mudstone, sandstone, breccias and conglomerates (Gerteisen, 1998). Under the microscope these rocks contains grains of $10-20 \%$ of broken plagioclase and mafic silicate minerals (amphibole>clinopyroxene) as well as minor volcanic lithic fragments. Theses clasts are contained in a plagioclase grainrich, very fine sand ot mud matrix. the clast is varies from rounded to angular, but is mostly subrounded to subangular, with width raining from $2-64 \mathrm{~mm}$ (granule to pebble) and locally exceed $100 \mathrm{~mm}$. Chlorite and calcite partially to completely replace the mafic silicate minerals. Plagioclase is locally replaced by epidoe. Magnetite, chlorite, epidote, calcite and minor pyrite are also present. The composition of clasts and matrix are probably derived from plagioclase-rich andesitic volcanic source closed to calc-silicate rock (Figure 2A).

\subsection{Tonalite porphyry intrusion}

This intruded rock which hosts the porphyry copper ores at the Batu Hijau has undergone 

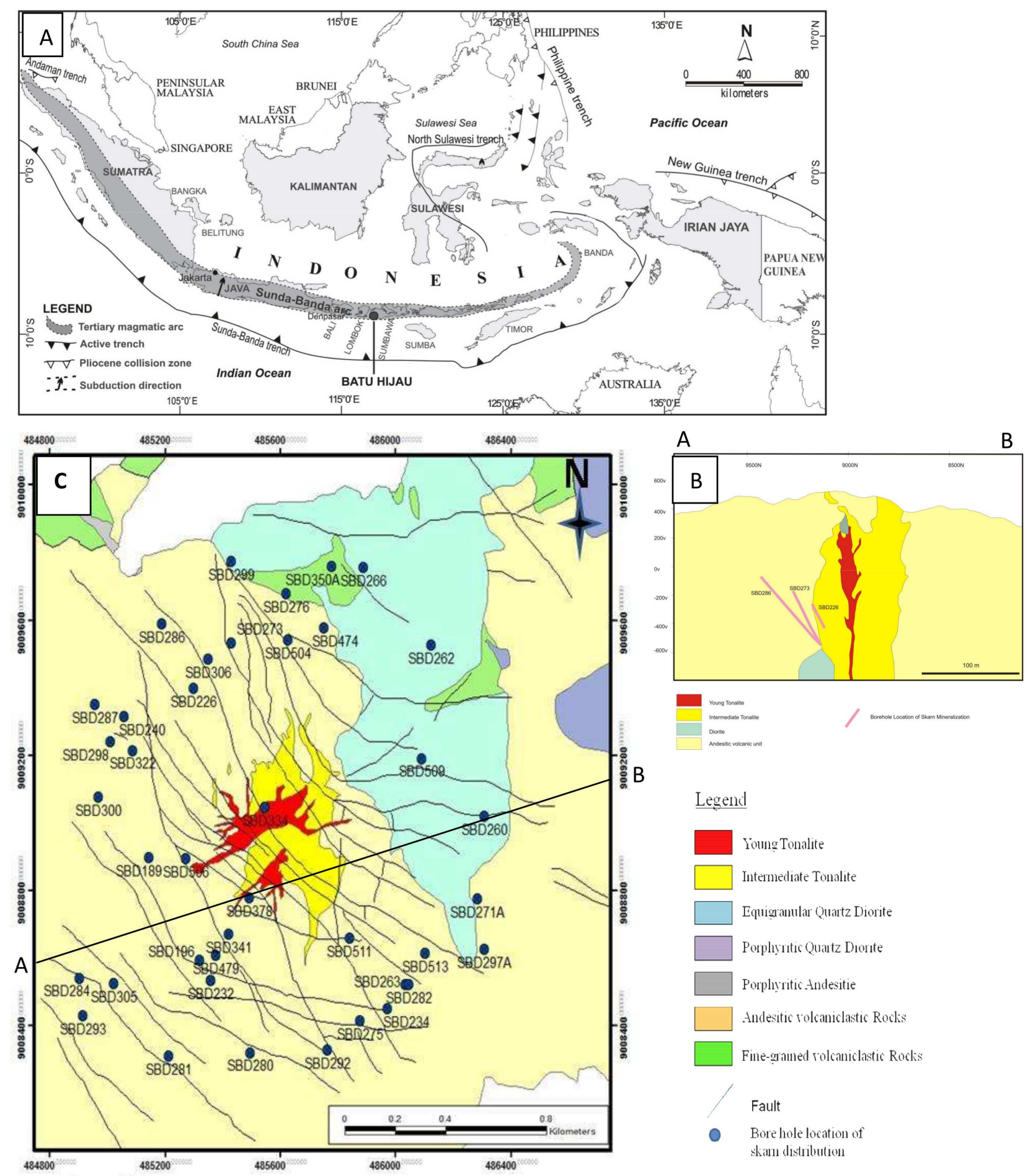

Legend

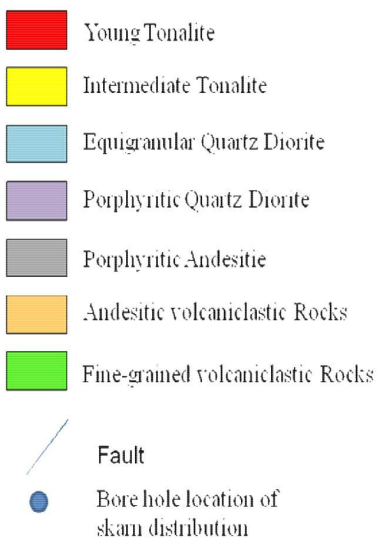

Figure 1: (a) Map of Indonesia showing the location of the Batu Hijau deposit; (b) geological map of the Batu Hijau deposit illustrating the bore hole location of skarn distribution (c) a profile of lithologic cross-section of porphyry and skarn contact along the direction A-B 
intense multiple hydro-fracturing and pervasive hydrothermal alteration processes. Although three phase of tonalte porphyry intrusions, intermediate tonalite porphyry intrusion is closely associated with skarn mineralization because skarn mineralization occurred along the contact of host rock, volcanic lithic breccias and intermediate tonalite porphyry intrusion. Under the microscope these rocks is characterized by light gray color and show typical porphyritic texture, containing phenocrysts of plagioclase (Figure 2B). Plagioclase is the predominant phenocrysts up to $10-25 \mathrm{vol} . \%$ of the rocks, and generally euhedral-subhedral and uniform in size from $2-3 \mathrm{~mm}$. The secondary biotite also was partially, to completely alter to chlorite and opaques (sulfides). Pyrite and chalcopyrite are the most abundant sulfide minerals and the most important copper ore in the intermediate tonalite stock.
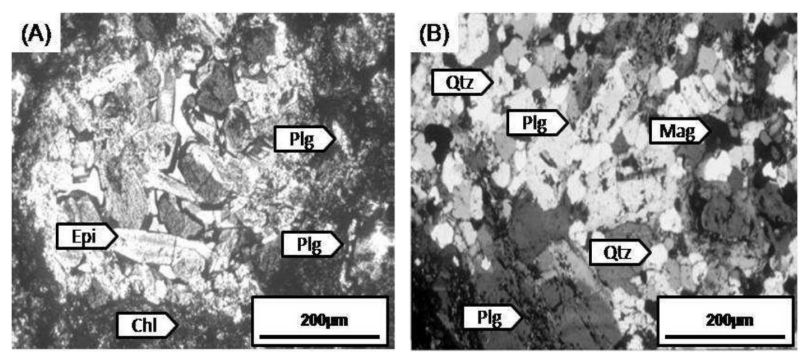

Figure 2: Photomicrographs of (A) the chloriteepidote-altered volcaniclastic rocks: Chlorite together with an aggregate of epidote, replacing plagioclase-containing clast in the rocks, and (B) the intermediate tonalite (plain polarized light)

\section{Skarn mineralogy}

Various types of anhyrous and hydrous calcsilicates (garnet, diopside, amphibole, epidote), silicates (chlorite, quartz, clay minerals), sulfides (pyrite, chalcopyrite, sphalerite, galena, bornite), oxides (magnetite, hematite) and carbonates (calcite) were developed during sequential stages of skarn forming processes in the skarn zones along the contact between intermediate tonalite porphyry stock and the volcanic rocks. Figure 3 showing the paragenetic sequence of minerals and ore in skarn at the Batu Hijau deposit.

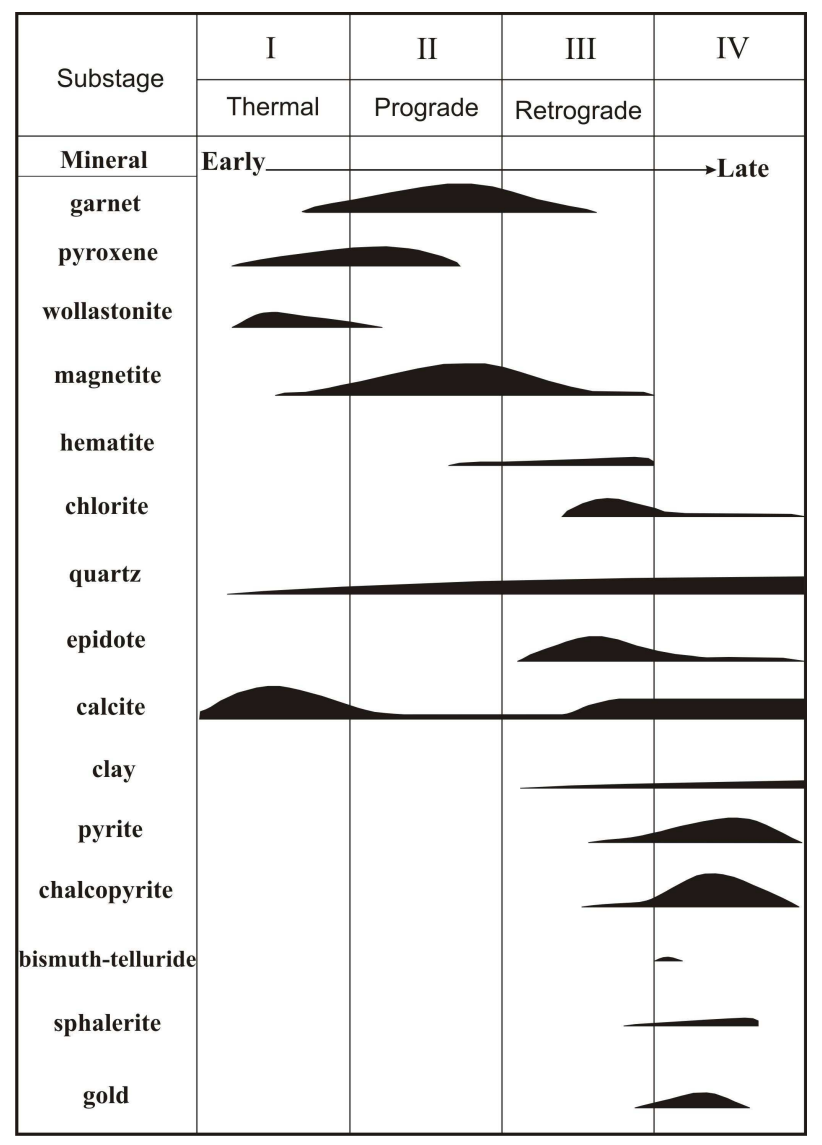

Figure 3: Paragenetic sequence of minerals present in skarn in the Batu Hijau deposit

Garnets occur ubiquitously in the skarn zone as fine to coarse-grained, anhedral to euhedral crystals. Most crystals display concentric zoning (Figure 4a). Textural examination shows that two types of garnets, belonging to different generations, (Figure $4 \mathrm{~b}$ ). are distinguishable as (1) fine-to medium-grained, anhedral to euhedral, reddish brown, anisotropic garnets which are mainly present in the outer parts of the skarn zone (proximal skarn), near the volcanic contact. Most garnet may be the product of metamorphic processes during which diffusion of elements between clay minerals and calcium rich in host rocks took place. (2) Mediumto coarse-grained, subhedral to euhedral, dark brown garnets, occurring principally in the vicinity of the contact. They occur as patchy aggregates with conspicuous growth zoning, and are isotropic. Coarse-grained anisotropic 
garnets have being altered to epidote and calcite (Figure 4c). Overall the SEM/EDX data show that the garnets are mainly andraditic garnet and most are partially, to entirely alter to epidote, calcite, quartz, \pm sulfides, \pm hematite, \pm chlorite and \pm clay minerals mainly along fractures and micro-fractures.

Clinopyroxenes occur as fine- to mediumgrained, anhedral to subhedral crystals showing decussate texture (Figure 4d). XRD and SEM/EDX data shows that the clinopyroxene are mainly diopside. They are cutting cross by magnetite veinlets and altered to chlorite (Figure $4 \mathrm{f})$.

They are partially to entirely alter to amphibole (tremolite-actinolite) (Figure 4d), quartz, calcite, \pm chlorite, \pm clay and \pm opaques (sulfides and oxides). The alteration is more pronounced along calcite micro-veinlets. Although compositional variations of the pluton and protolith exert a strong control on the mineralogy of the skarn zones (Meinert, 1995 and Ray et al., 1995), generally the higher ratios of garnet to pyroxene in the study area may be related to the oxidation state of the pluton and the wall rock (Meinert, 1997). Clinopyroxene occurs as vein which cut cross fine-grained garnet altered by chlorite (Figure 5a) and also cut crossed by quartz veinlets and magnetite veinlets in some (Figure 5b).

Epidote occurs as fine to medium-grained; anhedral to subhedral crystal aggregates showing granoblastic to decussate texture (Figure 5c) and are present mainly associated with garnets. The majority of epidote is the product of retrograde alteration by metasomatizing fluids. Most of garnets are replaced by epidote.

Amphibole (tremolite-actinolite) occurs as fine- to medium-grained fibrous and felted aggregates (Figure 5d) associated with the pyroxenes. Textural relationships suggest that they are the product of retrograde alteration of pyroxenes.

Chlorite is present as fine flakes within the anhydrous and hydrous calc-silicates (Figures $4 \mathrm{f}, 5 \mathrm{a})$. It appears to be a late-alteration product.

Quartz occurs as very fine- to mediumgrained patchy aggregates, dispersed and soli-
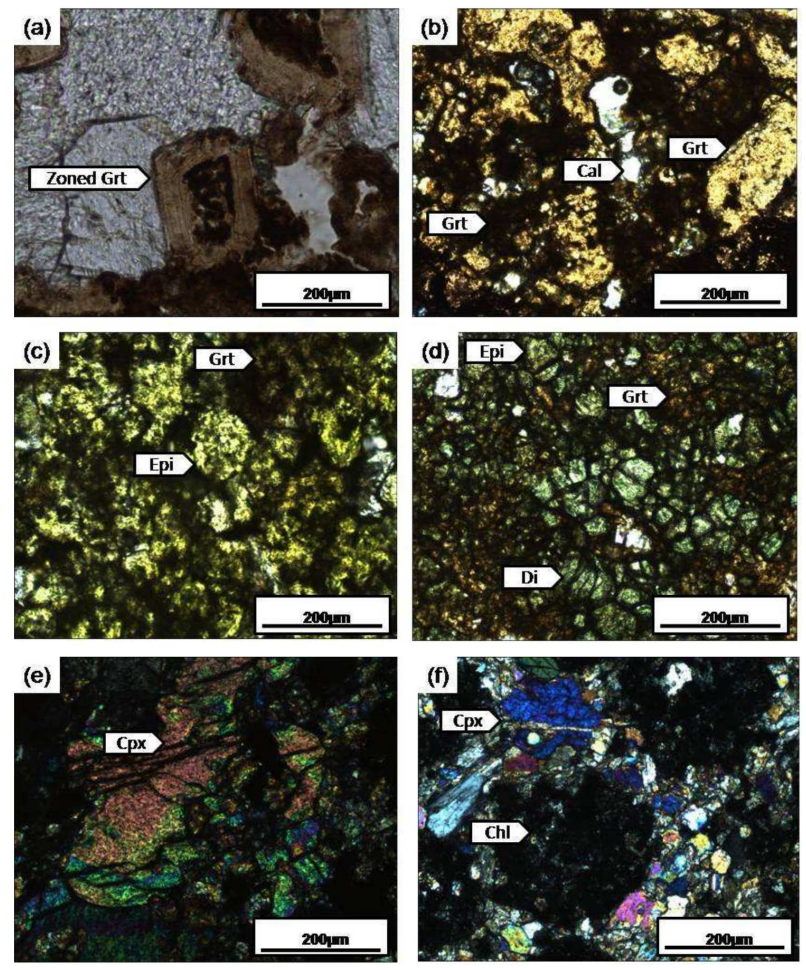

Figure 4: Photomicrographs of skarn samples: (a) concentric zoning in coarse-grained garnet, XPL; (b) two generation of gernet yellowish coarse-grained and and reddish brown medium-grained which replacement by garnet, XPL; (c) coarse-grained garnet being altered to epidote and calcite, XPL; (d) decussate texture in medium- to coarse-grained garnet and clinopyroxenes (Cpx), XPL; (e) decussate texture in medium- to coarse-grained clinopyroxenes (Cpx), XPL; (f) replacement of clinopyroxene by chlorite, $\mathrm{XPL}$

tary crystals, and as veinlets and micro-veinlets within the calc-silicates.

Chalcopyrite is relatively abundant and minute blebs of native gold generated in chalcopyrite associated with sphalerite (Figures $6 a-d)$. It partially to fully replaced by pyrite, and magnetite and occurs as intergranular aggregates as solitary crystals within magnetite (Figure 6e-f,7a). In some samples, sphalerite occurs as inclusion in chalcopyrite (Figure $7 \mathrm{~b}$ ). Occasionally it has been replaced partially by hematite.

Pyrite occurs mainly within calc-silicates as solitary and dispersed patchy aggregates 

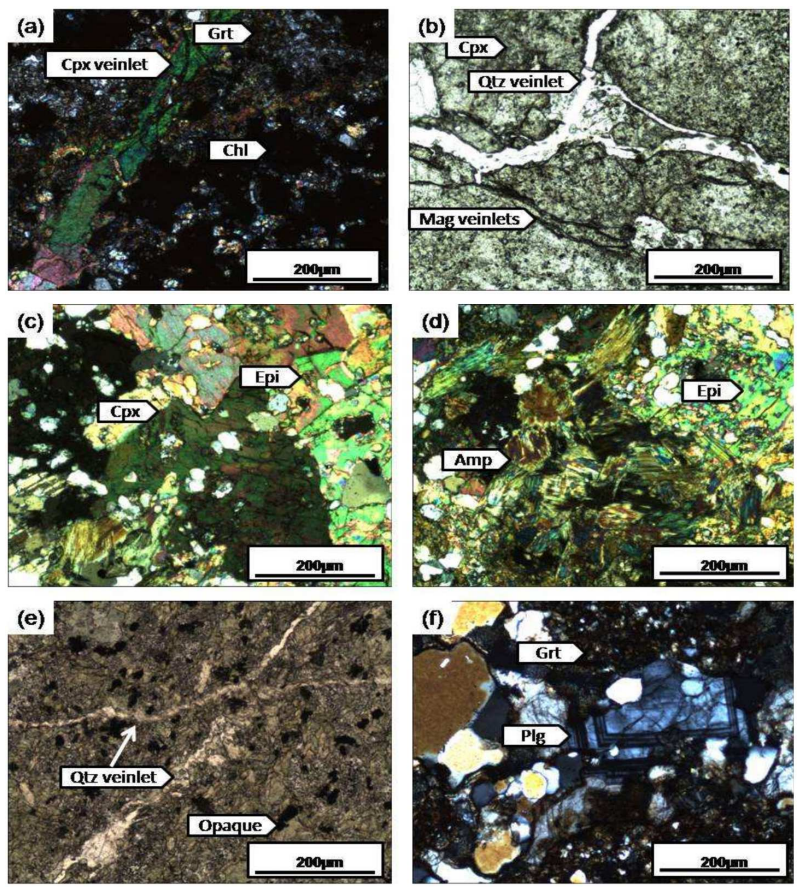

Figure 5: Photomicrographs of skarn samples: (a) Clinopyroxene occurs as vein which cut cross fine-grained garnet altered by chlorite, XPL; (b) clinopyroxene are cut crossed by quartz veinlets and magnetite veinlets, PPL; (c) Epidote showing granoblastic to decussate texture and mainly associated with garnets, XPL; (d) partial alteration of clinopyroxenes by amphiboles (tremolite-actinolite). XPL; (e) gernet associated opaque minerals are cut crossed by quartz veinlets and replacement of pyrite by chalcopyrite along the grain margin and fracture planes, PPL; (f) zoning plagioclase associated with garnets, XPL

and/or as veinlets and micro-veinlets. It replaces at the margin of chalcopyrite associated with sphalerite (Figure 7c).

Clay minerals are commonly accompanied by aggregates of very fine-grained calcite and hematite and appear to be a late alteration product.

Magnetite shows as patchy and aggregrate texture and contains lamellae of hematite (Figure $7 \mathrm{a}, \mathrm{f})$, and replaces pyrite (Figure $7 \mathrm{a}$ ) and is replaced partially by chalcopyrite and sphalerite (Figure $7 \mathrm{c}$ ). Garnet is mainly common within magnetite.

Sphalerite is observed associated with chal-
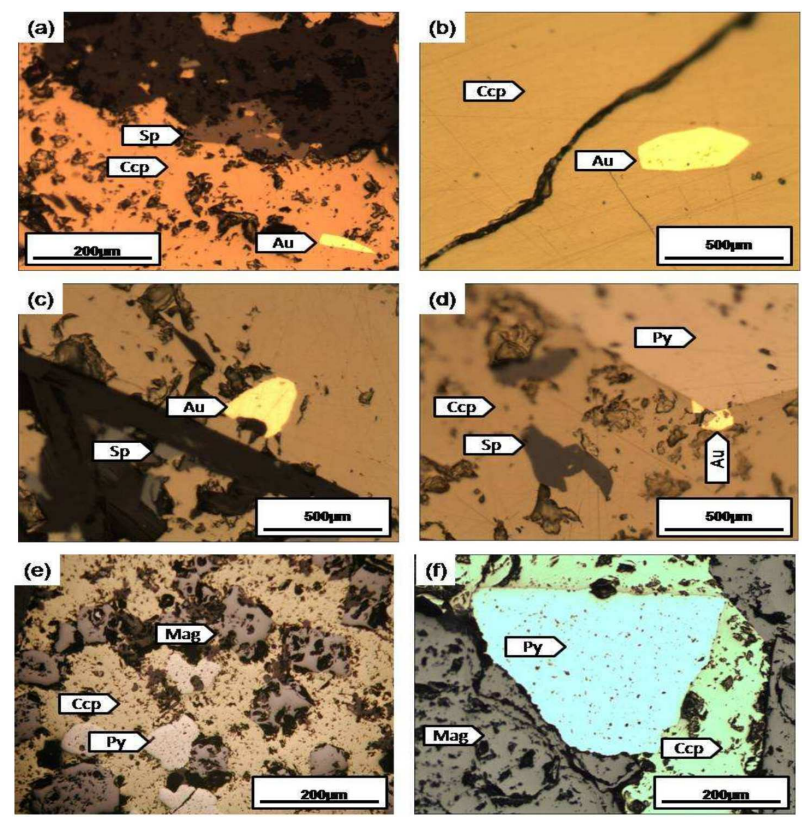

Figure 6: Photomicrographs of skarn ore samples. Polarized reflected light: $(a, b, c)$ blebs of native gold $(\mathrm{Au})$ generated in chalcopyrite (Ccp) associated with sphalerite (d) replacement of pyrite (Py) by chalcopyrite associated with native gold and sphalerite (Sp) (e) replacement of pyrite by magnetite and chalcopyrite (f) replacement of magnetite (Mag) by pyrite and chalcopyrite

copyrite, minute blebs of native gold and as inclusion within gold in some (Figure 6c). Sphalerite is partially replaced by magnetite and pyrite and chalcopyrite (Figure $7 \mathrm{e}-\mathrm{f}$ ).

Galena partially to completely replace by pyrite associated with sphalerite within chalcopyrite is also present (Figure 7d). Galena seems to have been the first sulfide mineral that was precipitated and was then replaced by pyrite.

Hematite occurs as bladed lamellae within magnetite (Figure 7f, 8a) and as fine-grained aggregates filling the micro-fractures in anhydrous calc-silicates and calcite. Hematite may partially replace pyrite and chalcopyrite.

Calcite occurs as very fine to coarse (up to $5 \mathrm{~mm}$ ) anhedral to subhedral crystals within the skarn zones. Medium- to coarse-grained crystals are also present in veinlets cutting calcsilicate aggregates, where they show decussate 

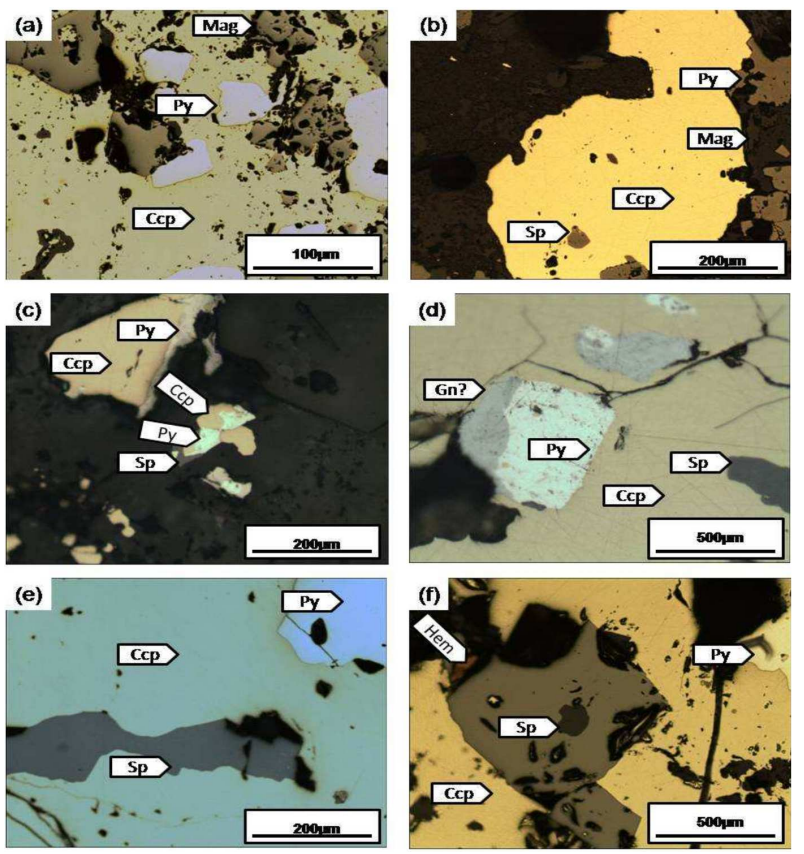

Figure 7: Photomicrographs of skarn ore samples. Polarized reflected light: (a) chalcopyrite (Ccp) replaced by pyrite (Py) and magnetite (Mag) (b) replacement of magnetite (Mag) by pyrite (Py), chalcopyrite (Ccp) and sphalerite (Sp); (c) pyrite (Py) replace at the margin of chalcopyrite (Ccp); (d) replacement of galena $(\mathrm{Gn})$ by pyrite (Py) associated with sphalerite (Sp); (e) pyrite and sphalerite replace chalcopyrite chalcopyrite (f) lamellae of hematite (Hem) within magnetite (Mag)

texture $(4 \mathrm{~mm})$. Some calcites along with quartz and opaques replace calc-silicates.

Sphene can be identified by SEM/EDX as inclusion in other minerals, euhedral crystals is occasionally present in the skarn zone (Figure 8c).

\section{Skarn forming processes}

Skarn-type metasomatic alteration occurred in the Batu Hijau as both endoskarn as exoskarn. Although endoskarn was developed only in some place within the intermediate tonalite intrusion, it is not clearly characterized by the presence of minerals to know endoskarn. But alteration minerals such as epidote tremolite-actinolite chlorite and calcite can be found.

Exoskarn is the major skarn zone in this area,
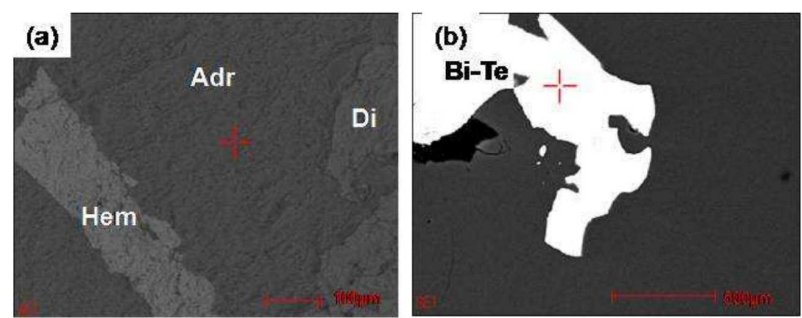

(c)

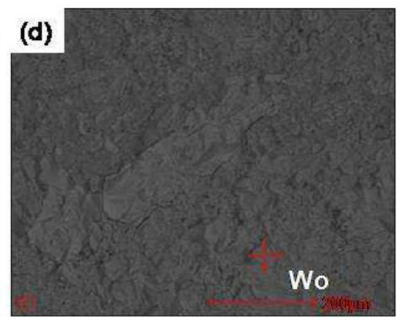

Figure 8: Photomicrographs of minerals and ore in skarn by SEM/EDX (Scanning Electron Microscope). Adr: andradite, Di: diopside, Hem: hematite, Bi-Te: bisumith-telluride, Spn: sphene, Kln: kaolinite, Wo: wollastonite

and contains copper and minor zinc sulfides (e.g. chalcopyrite and sphalerite). The thickness of this zone varies along the intrusive contact and locally reaches up to $400 \mathrm{~m}$ (by the bore hole). Garnet is the important anhydrous calcsilicate that is ubiquitously present within this zone. Pyroxene is not present in all samples of this zone and shows intense modal variations, and is locally more abundant than garnet. In general, the skarn rocks in this zone contain principally fine-grained calcite, garnet, pyroxene, epidote, chlorite, clays, and minor sulfides.

The reactions and the mineral assemblages formed in skarns usually depend upon the character of invaded rocks and the composition of the metasomatizing fluids and the overall pressure and temperature regime (Titley, 1973 and Guilbert and Lowell, 1974).

Based upon field evidence, along with mineralogic and petrographic data from intermediate tonalite porphyry intrusion and volcanic rocks and the skarn mineralization zone, the metasomatic alteration zones in the Batu Hijau can be classified as porphry-related calcic skarns. By taking mineralogical and textural criteria into consideration, the process of skarn can be cat- 
egorized into two discrete stages: (1) prograde and (2) retrograde.

Prograde: Temporally and spatially this stage is divided into two distinct sub-stages: 1 . metamorphic and 2. prograde metasomatism. Substage I was coeval with the initial emplacement of the tonalite porphyry intruded into volcanic rock, host rocks. The effect of heat flow from the pluton caused the enclosing rocks to become isochemically metamorphosed in the host rocks. However, in the clay-rich interlayers, in addition to recrystallized calcites, a series of fine-grained, Fe-poor calc-silicates (grossularitic garnet, diopsidic pyroxene, tremolitic amphibole, Fe-poor (epidote) and silicates (chlorite and quartz) were developed. Due to the high thermal effects, (near contact zone), a series of anhydrous and hydrous calc-silicates were developed within the rocks. No opaque minerals (oxides and/or sulfides) were formed during this sub-stage. In substage II, the crystallization of magmas is associated with the development of a volatile-rich phase (Candela and Piccoli, 1995). This sub-stage probably commenced with the consolidation and crystallization of the magma of porphyry intrusion. As crystallization progressed the volume of hydrothermal fluid is generated in the porphyry intrusion.

During sub-stage I, metamorphic alteration was accompanied by decarbonation reactions that cause slight volume decrease and lead to the formation of fractures. This type of fracturing, with those resulting from upward pressure exerted by the ascending magma, and the evolving fluid phase (hydro-fracturing), developed possibility for the infiltration fluids into near the host rocks. It can be formed during the sub-stage I. Evidence of the metasomatic alteration which occurred during this sub-stage is provided by medium to coarse-grained Fe-rich anhydrous calc-silicate minerals which overprinting almost entirely the sub-stage I assemblages. During sub-stage II, coarse-grained garnets with a granoblastic texture were developed. The replacement of sub-stage I assemblages by andradite-grossularite may suggest strongly that substantial quantities of dissolved components such as $\mathrm{Fe}, \mathrm{SiO}_{2}$, and $\mathrm{Mg}$ was transferred into the skarn system by metasomatizing hydrothermal fluids.

These prograde anhydrous calc-silicate assemblages in skarn can be correlated with the characteristic potassic alteration in the mineralized pluton Meinert (1992). By accepting this premise, the fluid inclusion data from the intermediate tonalite porphyry intrusion indicate that the temperature of these magma-derived fluids was possibly $>515^{\circ} \mathrm{C}$ (by fluid inclusion data) and caused the prograde metasomatic alteration, particularly in the proximity of the intrusive contact.

Retrograde stage: In some porphyry-related deposits, intense retrograde alteration is common in copper skarns (Meinert, 1992) may destroy most of the prograde anhydrous calcsilicates, (e.g. Ely, Nevada; James, 1976). The presence of numerous cross-cutting veinlets and micro-veinlets of quartz, quartz-sulfide, sulfide, calcite, magnetite in anhydrous calcsilicates, which are extent in the adjacent to the porphyry intrusion, may suggest a coincidence of the hydro-fracturing phases during phyllic alteration in the prograde skarn zone in tonalite porphyry intrusion. generally there is a correlation between characteristic phyllic alteration in mineralized pluton in PCD and retrograde hydrous calc-silicate assemblages in skarn (Einaudi, 1982a and Meinert, 1992). Such a correlation between Porphyry Stock and the associated skarn zone in Batu Hijau can be reasonably proposed.

Mineralogical and textural studies show that the retrograde stage can also be divided into two distinct (1) early and (2) late sub-stages. During the early of retrograde stage (substage III), large amounts of anhydrous calcsilicates were replaced by a series of hydrous calc-silicates (epidote, \pm tremolite-actinolite), sulfides (pyrite, chalcopyrite and sphalerite), oxides (magnetite, hematite) and carbonates (calcite), mainly along the fractures and microfractures. Epidote is the most common alteration mineral. In the late retrograde stage (sub-stage IV), the development of retrograde assemblage may characteristically continue 
hydrofracturing processes and prolonged hydrothermal activity operating in both the mineralized porphyry intrusion and in the adjacent skarn zone. During this sub-stage both anhydrous and hydrous calc-silicates were altered to low temperature fine aggregates minerals as calcite, clay, chlorite and hematite along fractures and micro-fractures.

\section{Mineralization}

Mineralogical and textural studies suggest that no opaque minerals (oxides and/or sulfides), were formed in the marmorized and skarnoid-hornfelsic rocks during sub-stage I. Textural evidence, such as lack of intergrowth and non-replacive crystal boundaries between opaques and anhydrous calc-silicates, indicates that opaques did not form, even during prograde metasomatism. The existence of replacement textures between opaques and anhydrous calc-silicates and open-space filling textures in fractures within anhydrous calcsilicates, and of intergrowths between opaques and hydrous calc-silicates (epidote, tremolite-actinolite), provide compelling evidence that most opaques and hydrous calc-silicates were developed during early retrograde alteration (sub-stage III). Textural relationships among hypogene opaque minerals also indicate that paragenetically their temporal order of deposition is as follows: galena $\rightarrow$ pyrite $\rightarrow$ magnetite + primary hematite $\rightarrow$ chalcopyrite + sphalerite.

The crytallization of opaques seems to be controlled chiefly by fractures, open spaces, and the composition of anhydrous calc-silicates. The concentration of opaque minerals is mainly in the metasomatic skarn zone. The abundance and type of opaques varies spatially, depending upon their locality and distance from the intrusive contact. Sulfides are predominantly present in the skarn zone.

In many porphyry related skarns, the fluids involved in potassic and phyllic alterations of the mineralized pluton are responsible for prograde and retrograde alteration processes in the skarn zone respectively (Einaudi, 1982a and Meinert, 1992). Temporal and spatial variations of physico-chemical conditions such as pressure, temperature and some important volatile components in the hydrothermal fluids during skarnification processes were analyzed through mineral paragenesis, textural relationships, stability field of the dominant calc-silicates, and fluid inclusion data from the adjacent mineralized intermediate tonalite porphyry intrusion.

Sulfur isotopes data from 12 sulfide samples (e.g. pyrite, chalcopyrite and bornite) mainly from porphyry mineralization and from four sulfide samples (e.g. pyrite, chalcopyrite) in skarn show that their $\delta^{34} \mathrm{~S}$ values range from -0.1 to $1.7 \%$. These values indicate a magmatic source for the sulfur (Ohmoto and Rye, 1979) in both mineralized porphyry and the associated skarn zone. Therefore, it may be suggested that the sulfur within the skarn zone originated from a magmatic source and was transferred into the skarn system by the metasomatizing fluids which in most likelihood was responsible for the alteration and associated sulfide mineralization in the porphyry mineralization.

Depth of skarn formation has strong control in the extent of the skarn, its geometry, and style of alteration (Meinert, 1992). Fluid inclusions can be used for quantitative geobarometric studies. Fluid inclusion data from quartz samples collected from the samples associated with pyroxene abundant skarn, garnet abundant skarn and near mineralization vein in the bore hole SBD-252/1031, 226/694, 273/930, $286 / 814$ near the porphyry contact was used to calculate the approximate depth of skarn formation. The estimated depth is $\sim 1800 \mathrm{~m}$ which was calculated on the basis of hydrostatic pressure head obtained from halite-bearing inclusions having $\mathrm{T}_{\mathrm{S}}(\mathrm{NaCl}) \approx \mathrm{T}_{\mathrm{H}}(\mathrm{L}-\mathrm{V})$ (Calagari, 1997). Therefore, the skarn zone in the present of the study area can be postulated to have been developed in hypabyssal environment at a depth of $\sim 1800 \mathrm{~m}$. The fluids contained Fe, Si, and $\mathrm{Mg}$ with high activity, and were relatively at oxidizing state causing decarbonation reactions and development of Fe-rich anhydrous calc-silicates. Andradite thus formed was stable with the fluid in equilibrium with porphyry intrusion

The development of low-temperature min- 
eral assemblages such as chlorite and clay minerals, along with very fine aggregates of secondary hematite and calcite, within the early-formed assemblages may suggest that the late metasomatizing fluids (sub-stage IV) were probably at a higher oxidation state and as a result that the porphyry system with sulfurbearing magmatic fluid probably causing the oxidation of sulfur.

\section{Discussion and conclusions}

Skarn mineralization in the Batu Hijau were developed along the contact of the andesitic volcanic rocks with the intermediate tonalite porphyry intrusion. Overall data shows

Field evidence, analytical data, and mineralogical and textural criteria show that in the study area probably the skarn in the Batu Hijau derived from the volcanic rock as it is calcic in composition. Furthermore, genetically the formation of skarn processes and their evolutionary trend can be categorized into two discrete stages: (1) prograde and (2) retrograde. The prograde stage can be divided temporally into two distinct sub-stages: (a) early prograde, metamorphism and (b) prograde metasomatism.

Metamorphic alteration (sub-stage I) originated shortly after the intrusion of the intermediate tonalite porphyry into calcium rich host rock. The alteration progressed isochemically by the effects of heat flow from the pluton into the surrounding cacic rich rocks. The thermal effects caused layers to recrystallize metamorphically into calcic rich rocks. In general, some anhydrous calc-silicates in proximity to the contact (higher temperature), and some hydrous ones at distances farther away, were developed by metasomatic processes from clay-rich interlayers during this sub-stage. The development of these calc-silicates is usually accompanied by decarbonation reactions which cause a slight volume decrease and the subsequently formation of fractures and micro-fractures in the host rock. Since, the protolith was lacking in $\mathrm{Fe}$, the calc-silicates formed during this sub-stage were Fe-poor garnets and pyroxenes. Almost no opaque minerals (oxides and sulfides) were formed during sub-stage I.

Prograde metasomatic alteration (sub-stage II) commenced with the beginning of crystallization and consolidation of porphyry intrusion have concurrent separation of high temperature fluids. The invasion and infiltration of such fluids into secondary fractures, resulted from both decarbonation reactions and hydrofracturing processes, transferred to $\mathrm{Fe}, \mathrm{Si}$ and $\mathrm{Mg}$ to the contact zones. The introduction of these elements caused the further evolution of the decarbonation processes and the formation of medium to coarse-grained anhydrous calcsilicates within a fine-grained matrix. The intensity of alteration during sub-stage II was so high that in proximal zone to become obscured or completely obliterated. Two kinds of generations of garnets were also developed during sub-stage II.

Garnets and pyroxenes formed during substage II are mainly andraditic and hedenbergitic in composition, respectively, which may be due to the introduction of considerable amounts of Fe into the skarn system by the invading fluids. Textural relationships indicate that opaque minerals were not formed during sub-stage II.

Based upon mineralogical and textural data, the retrograde metsomatic alteration can be divided into two distinct sub-stages: (1) early retrograde (sub-stage III) and (2) late retrograde (sub-stage IV). During sub-stage III, the prograde metasomatic alteration zones were probably affected by hydro-fracturing, produced numerous channels for the infiltrating hydrothermal fluids. As long as the temperature of such fluids was $>515{ }^{\circ} \mathrm{C}$ by fluid inclusion data, the calc-silicates in skarn zones remained stable. The considerable amounts of hydrous calc-silicates (epidote, tremolite-actinolite), sulfides (sphalerite, chacopyrite, and pyrite), oxides (magnetite, hematite), and carbonates (calcite) replaced the early-formed anhydrous calc-silicates. Additionally, copper sulfide mineralization also can be occurred mainly during sub-stage III.

The early-formed mineral assemblages were altered to a series of fine-grained aggregates of chlorite, hematite, calcite and clay chiefly along 
fractures and micro-fractures by relatively low temperature and low $\mathrm{pH}$ fluids may have been a relatively higher oxidation state during late retrograde alteration (sub-stage IV).

\section{Acknowledgements}

This study has been supported financially by AUN/SEED-Net, JICA. The authors would like to acknowledge and express their sincere thanks and appreciations to Prof. Korichio Watanabe. Our gratitude is further expressed to Mine Geology Department, Newmont, Indonesia for their kind supporting and kind helps during the field work.

\section{References style}

Calagari, A.A. (1997) Geochemical, stable isotope, noble gas, and fluid inclusion studies of mineralization and alteration at Sungun porphyry copper deposit, East Azarbaidjan, Iran: Implication for genesis. Unpublished PhD Thesis, Manchester University, 537p.

Candela, P.A., Piccoli, P.L. (1995) Model oremetal partitioning from melt into vapor and vapor/brine mixtures. In: Thompson, J.F.H. (Ed.), Magmas, Fluids and Ore Deposits. Mineralogical Association of Canada Short Course Handbook, vol. 23, pp. 101-127.

Einaudi, M.T. (1982a) General features and origin of skarns associated with porphyry copper plutons, Southwestern North America. In: S.R. Titley, Editor, Advances in the Geology of Porphyry Copper Deposits, The University of Arizona Press, Southwestern North America, Tucson, pp. 185-209.

Einaudi, M.T. (1982b), Description of skarns associated with porphyry copper Plutons, southwestern North America. In: S.R. Titley, Editor, Advances in the Geology of Porphyry Copper Deposits, The University of Arizona Press, Southwestern North America, Tucson (1982), pp. 139-184.

Einaudi. M.T., L.D. Meinert and R.J. Newberry (1981) Skarn deposits, Economic Geology, pp. 317-391 (75th Anniversary Volume).

Gerteisen, C. (1998) Volcanic stratigraphy of the Batu Hijau porphyry copper-gold deposit, southwest Sumbawa, Indonesia: Unpublished report submitted as partial fulfilment of a M.Sc. degree at Curtin University, Kalgoorlie, School of Mines, $53 \mathrm{p}$.

Guilbert, J.M. and J.D. Lowell (1974) Variations in zoning patterns in porphyry copper deposits, Canadian Institute of Mining and Metallurgy Bulletin 67, pp. 99-109.

Idrus, A., Kolb, J., Meyer, F. M., Arif, J., Setyandhaka, D., Keply, S. (2009b) A preliminary study on skarn-related calc-silicate rocks associated with the Batu Hijau porphyry copper-gold deposit, Sumbawa Island, Indonesia. Resource Geology, vol. 59, No.3, pp.295-306

James, A.H. (1976), Zoned alteration in limestone at porphyry copper deposits, Ely, Nevada, Economic Geology 71, pp. 488-512.

McPhie, J., Doyle, M., Allen, R. (1993) Volcanic textures; a guide to the interpretation of textures involcanic rocks: Launceston, TAS, Australia, University of Tasmania, Centre for Ore Deposit andExploration Studies, 196 p.

Meinert, L.D. (1992), Skarn and skarn deposits, Geoscience Canada 19 (4), pp. 145-162.

Meinert, L.D. (1995) Compositional variation of igneous rocks associated with skarn deposits-chemical evidence for a genetic connection between petrogenesis and mineralization. In: Thompson, J.F.H. (Ed.), Magmas, Fluids and Ore Deposits. Mineralogical Association of Canada Short Course, vol. 23, pp. 401-418.

Meinert, L.D. (1997), Application of skarn deposit zonation models to mineral exploration, Exploration and Mining Geology 6, pp. 185-208.

Ohmoto, H. and R.O. Rye (1979), Isotopes of sulfur and carbon. In: H.L. Barnes, Editor, Geochemistry of Hydrothermal Ore Deposits, Wiley, New York, pp. 509-567 see also 798 p.

Proffett, J.M., (2003) Review of deep drilling results at Batu Hijau. Unpublished Newmont Nusa Tenggra Company Report. PT. Newmont Nusa Tenggra, Batu Hijau project, Sumbawa, Indonesia. 6p.

Ray, G.E., I.C.L. Webster and A.D. Ettlinger (1995), The distribution of skarns in British Columbia and the chemistry and ages of their related plutonic rocks, Economic Geology 90, pp. 920-937

Setyandhaka, D., Proffett, J.M., Kepli, S., and Arif, J., (2008) Skarn Mineralization in Batu Hijau CuAu porphyry system. Proceeding of 37th annual meeting of Association of Indonesian Geologist, Bandung, 664-671.

Titley, S.R. (1973), Pyrometasomatism-an alteration type, Economic Geology 68, pp. 1326-1328. 